\title{
Analysis and Energy Certification of an Andalusian Public Health Center. Comparative between the General Option and Simplified Procedures ${ }^{\dagger}$
}

\author{
Montiel-Santiago Francisco Javier 1,2, Hermoso-Orzáez Manuel Jesús ${ }^{2, *}$, Terrados-Cepeda Julio ${ }^{2}$ \\ and Brito Paulo ${ }^{3}$ \\ 1 Hospital of Jaén Maintenance Service, Servicio Andaluz de Salud, 23007 Jaén, Spain; \\ javier.montiel.sspa@juntadeandalucia.es \\ 2 Department of Graphic Engineering Design and Projects, Universidad de Jaén, 23071 Jaén, Spain; \\ jcepeda@ujaen.es \\ 3 I.I.P. Portalegre, Campus Politécnico Portalegre, 10|7300-555 Portalegre, Portugal; pbrito@ipportalegre.pt \\ * Correspondence: mhorzaez@ujaen.es; Tel.: +34-610-389-020 \\ + Presented at the 5th Ibero-American Congress on Entrepreneurship, Energy, Environment and \\ Technology-CIEEMAT, Portalegre, Portugal, 11-13 September 2019. \\ Published: 26 December 2019
}

\begin{abstract}
The requirements concerning the energy certification of buildings established in Directive 2002/91/EC of the European Parliament and of the Council of 16 December 2002, which was in turn modified by Directive 2010/31/EU of the European Parliament and of the Council, of 19 May 2010, regarding the energy efficiency of buildings, were transposed into Spanish legislation through Royal Decree 47/2007, dated January 19, through which a Basic Procedure for certification was approved of energy efficiency of new buildings, which was consolidated by Royal Decree 235/2013, of April 5, which approves the basic procedure for the certification of the energy efficiency of buildings. In said Royal Decree, it is established that existing buildings or units of buildings occupied by a public authority, must obtain an energy efficiency certificate and will have the obligation to display their energy efficiency label, when their total useful area exceeds $250 \mathrm{~m}^{2}$, and are usually frequented by the public. The Basic Procedure is established that must comply with the methodology for calculating the energy efficiency rating, considering those factors that have the greatest impact on their energy consumption, as well as the technical and administrative conditions for the energy efficiency certifications of the buildings. For this purpose, three software programs were promoted from the competent Ministry, one corresponding to the general option (LIDERCALENER "HULC" unified tool) and two others corresponding to the simplified option (simplified procedures CE3 and CE3X), which allow the energy qualification to be carried out of buildings according to three types of buildings (residential, small and medium-sized tertiary, and large tertiary) that are increasing the requirements of the energy certification of the building depending on the type of the same. This study identifies the possible alternatives for improving energy efficiency over the initial qualification of the building, within a context of technical and economic feasibility, optimizing energy demand, reducing $\mathrm{CO}_{2}$ emissions and building energy consumption, being The study also compares the results obtained in the energy rating, between the general option and the simplified procedures, on an Andalusian health center in 1957, which corresponds to the typology of the Grand Tertiary building (GT).
\end{abstract}

Keywords: energy-certification; efficiency-energy-buildings; emissions $\mathrm{CO}_{2}$; environmental efficiency; sustainable-development; economic efficiency 


\section{Introduction}

The present document on Energy Qualification of a Health Center dating from 1957, is based on the basic procedure for the certification of energy efficiency of buildings, approved according to Royal Decree 235/2013 [1], which partially transposes Directive 2010/31/EU [2], Energy Efficiency in Buildings, to Spanish legislation. This Regulation establishes that existing buildings or units of buildings occupied by a public authority, must obtain an energy efficiency certificate and will have the obligation to display their energy efficiency label, when their total useful area exceeds $250 \mathrm{~m}^{2}$, and they are frequented usually by the public. In this work, the results obtained when performing the energy qualification of an Existing Building dating from 1957 are exposed, which in this case, is the Health Center "Virgen de Linarejos" of Linares (Jaén, Spain), belonging to the Service Andalusian of Health and that attends to the typology of Gran Tertiary building (GT).

\section{Methodology}

The Basic Procedure for the certification of energy efficiency of buildings, approved according to Royal Decree 235/2013, establishes the methodology for calculating the energy efficiency rating, considering those factors that have the greatest impact on their energy consumption, as well as the technical conditions and administrative for energy efficiency certifications of buildings. For this purpose, three software programs were promoted from the competent Ministry, one corresponding to the general option (LIDER-CALENER "HULC" unified tool) and two others corresponding to the simplified option (simplified procedures CE3 and CE3X), which allow the energy qualification to be carried out of buildings according to three types of buildings (residential, small and medium-sized tertiary, and large tertiary) that are increasing the requirements of the energy certification of the building depending on the type of the same. Through the aforementioned official programs, the energy rating of this health center of the Andalusian Health Service will be carried out, as well as the analysis of measures to improve the energy efficiency of the Building.

\subsection{Object of Study}

This paper analyzes the energy rating of an Existing Building with a Gran Tertiary (GT) typology, specifically a Health Center of the Andalusian Health Service, dating from 1957, located in the province of Jaén (Spain). This energy rating allows to check the current energy status of the building and to study possible alternatives for improving energy efficiency over the initial rating of the building, within a context of technical and economic feasibility, optimizing energy demand, reducing $\mathrm{CO}_{2}$ emissions and the energy consumption of the building, being also the object of the study, the comparison of the results obtained in the energy qualification, between the general option and the simplified procedures promoted by the competent Ministry.

\subsection{Case Study}

The Health Center "Virgen de Linarejos" is a health center of the Andalusian Health Service, which belongs to the Ministry of Health of the Junta de Andalucía, located in Linares (Jaén, Spain), corresponding to climate zone C4, according to Code Building Technician (CTE) [3]. The construction of the building dates from 1957 to 1960, through the National Social Security Institute belonging to the Ministry of Labor, destined as a Health Insurance Outpatient. In the year 2000, a reform of the Health Center is carried out, to adapt it to the requirements of the Andalusian Health Service. This reform does not affect the structure or the enclosures of the building, although if the carpentry of the building is reformed, as well as all the air conditioning and Sanitary Hot Water (SHW) facilities. The main activity is the building, which corresponds to a Primary Care Health Center with an Emergency Device. As complementary activity in the building are the offices for administrative use of the Jaén Norte Sanitary District. 


\subsubsection{Building Description}

The "Virgen de Linarejos" Health Center is located in a $1020 \mathrm{~m}^{2}$ building with a very elongated rectangular plan and has 6 floors built on the ground and a basement. The total constructed area is approximately $4200 \mathrm{~m}^{2}$. The 7 floors in which the building is divided are: Basement, Ground, First to fifth. The building is of variable section, since from the second floor, the constructed area is reduced, and the basement does not occupy the entire floor of the building. The building is made of reinforced concrete structure and the walls of the exterior enclosure are plastered brick factory, smooth finish monolayer and white stone exterior paint, they have a half-foot chamber and a second brick brick wall [4]. There are also other types of enclosure walls that contain land that is made of 250 mass concrete. The building slabs are also reinforced concrete. The exterior carpentry is white lacquered aluminum with simple $6 \mathrm{~mm}$ glass without thermal break. The interior distribution is made with brick wall partitions plastered and plastered according to the description of the finishes. The building has 2 types of roofs, being the main roof of the curved, four-water tile building, not passable and the second type of roof is flat and invertible of medium arid, forming the terraces accessible from the second floor. The pavements are mainly of terrazzo, existing some areas in the general accesses with marble finish. The coatings are ceramic veneered in toilets, plaster plaster and painted. A picture of the building is shown in Figure 1.

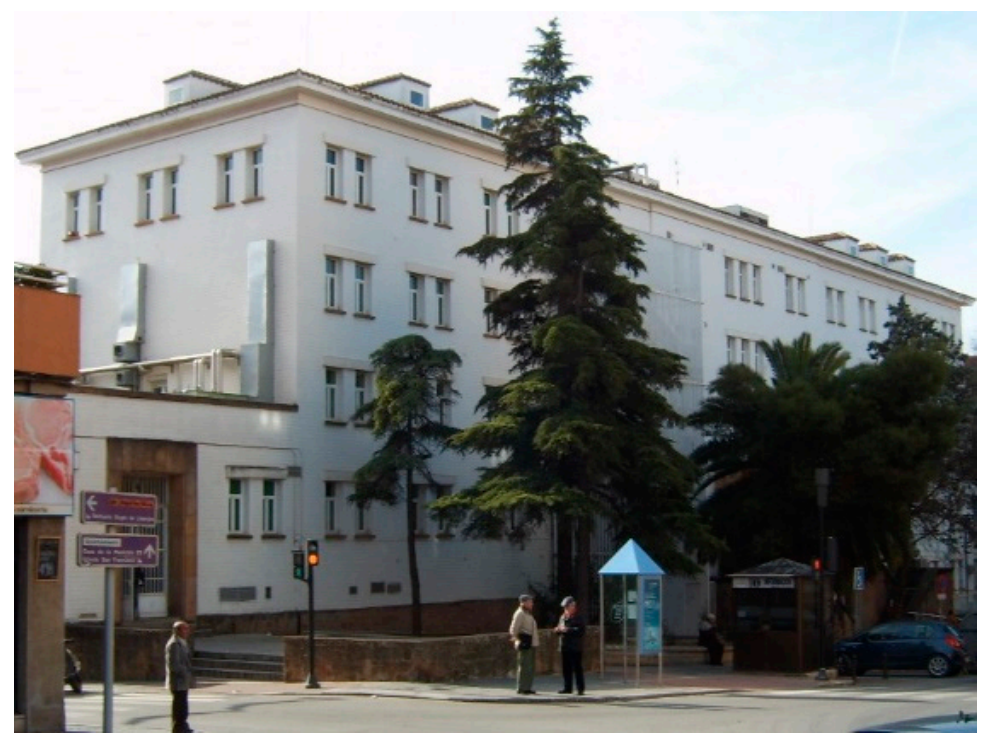

Figure 1. General view of the Virgen de Linarejos Health Center.

\subsubsection{Description of the Building's Air Conditioning and Sanitary Hot Water (SHW) Systems}

With regard to the production of cold, the air conditioning system of this building has two clearly differentiated slopes:

- On the one hand there is a centralized production through two air-water chillers that supply a series of air handling units with ducts.

- On the other hand, to acclimatize the rooms in the Emergency Zone, which have a totally different use schedule than the rest of the Center, there are a series of autonomous teams divided into several models and powers that supply these premises. This equipment also has a heat pump system.

For the generation of heat, there is a boiler fueled with diesel, in order to supply hot water for air conditioning. In this case apart from the supply of hot water to the treatment units of common waiting areas as in the case of cold production, there is also a series of water radiators located in all the perimeter areas of the building, covering practically all the Center, including the emergency area.

The distribution of water for air conditioning is carried out by means of a two-pipe installation, which does not allow simultaneous demand for heat and cold. The air conditioning units with 
constant air flow with cold and heat battery, have return temperature regulation, with actuation on three-way valve of proportional type.

The production of Sanitary hot water (SHW) is carried out with electric water heaters located in each of the different verticals that feed the endpoints of consumption.

\subsubsection{Building Definition for Energy Simulation}

In this section it is necessary to define all the data necessary to qualify the Health Center with the general HULC option. These data are those referring to the epidermis, climate and operational and occupational characteristics, as well as the definition of the building systems and the assignment of said systems to the corresponding spaces.

First, it was based on the plans of the building in " $\mathrm{dxf}$ " format, which served as a template for the construction of the geometry of the Health Center through the unified tool program LIDERCALENER (HULC) [5-7]. Once the geometry was obtained, the configuration of the thermal envelope materials of the building, the operational and occupational characteristics of the spaces, the unified tool program, the building exports to the CALENER GT program, after calculating the thermal demand.

Once the geometry, the thermal envelope, the operational and occupational characteristics have been achieved, the definition of all the Health Center's systems, as well as the allocation of spaces to them, is already carried out in the CALENER GT program, in order to So, finally get the current rating of the building. The results of the final qualification and the report of the same are already obtained in the HULC program. Figure 2 shows the image of the building in the HULC program.

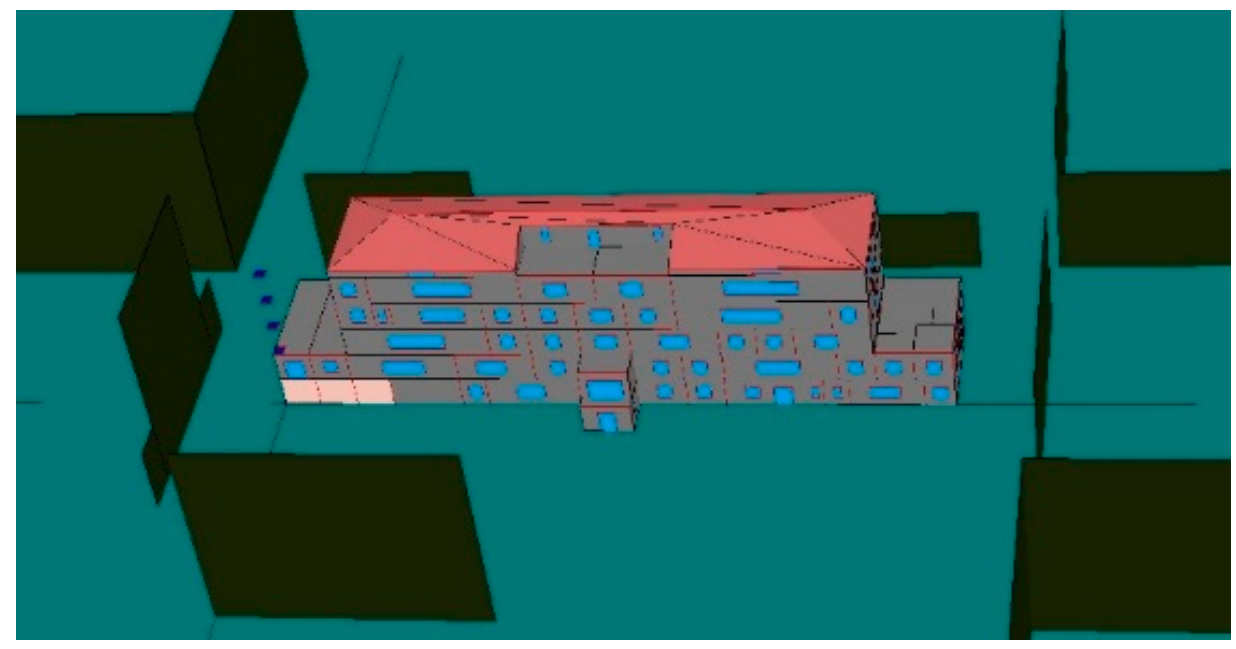

Figure 2. Building geometry in the HULC program.

\subsubsection{Considerations for Introducing the Geometry of the Building for Energy Simulation}

Due to the large size of the Health Center and the limitations of the program, there was no solution but to simplify reducing spaces and building elements. The real geometry of the building has 154 spaces and exceeded the calculation limit recommended by the program and gave errors when performing the simulation, so that geometry had to be modified because HULC does not support more than 100 spaces and 500 elements in the definition of geometry. Finally, the geometry was reduced to 86 spaces, and the windows were reduced to 110 (one per enclosure), given that the real windows of the building are 395, which together with the rest of the building's elements exceeds the established limit. In order to obtain this reduction of spaces, spaces of similar characteristics of the interior of the Health Center have been joined, especially unconditioned spaces, as well as administrative offices and consultations, fed by the same air treatment unit.

In order to be able to make a comparison of the results between the general option "HULC", and the simplified procedures "CE3" [8] and "CE3X" [9], the same zoning of building spaces will be 
maintained for the three energy qualification programs, taking care of course to the specifications of each program that are not the subject of this work.

\subsubsection{Proposals to Improve the Energy Efficiency of the Building}

The modifications proposed to improve the Energy rating of the Health Center are the following [10-12]:

(1) Energy Demand Improvements: increased insulation of exterior enclosures, replacement of glazing with low emissives and decrease of infiltrations.

(2) Improvements in Equipment and Systems: replacement of heating and DHW fuel, improvement of thermal/mechanical performance of primary equipment, increase in the performance of air conditioners, increase in the efficiency of luminaires and integration of renewable energies in the building.

The list of improvement measures studied on the energy rating of the building is listed below:

- M1: Increase the quality of holes in the envelope. Replacement of double glazed windows with low emissivity, thermal bridge breakage and increased quality of carpentry against infiltration.

- M2: Increased insulation of the building's thermal envelope. Insulation placement in the enclosures and exterior floors, and on the roof of the building, until adapting the building enclosures to the limit values required by the DB-HE of the CTE, in climate zone C4 for new buildings.

- M3: Replacement of heating fuel (diesel with natural gas).

- M4: Replacement of conventional diesel boiler with one of biomass of similar power.

- M5: Replacement of conventional diesel boiler with one of natural gas condensation of similar power.

- M6: Replacement of chillers with others of high efficiency of similar power.

- M7: This improvement alternative encompasses improvements M1, M5 and M6.

- M8: improvement of the energy efficiency of the building lighting installation (installation of LED type luminaires), together with the previous M7 alternative.

\section{Results}

In the first place, the results obtained from the energy rating of the Health Center with the general option ("HULC" program) and the proposed improvement alternatives are presented, and in a second part the results obtained with the simplified procedures are presented (programs CE3 and CE3X), ending with the comparison of the results between the general option and the simplified procedures.

\subsection{Result Obtained in the Energy Rating of the Building with the General Option HULC}

As can be seen in Figure 3, the rating obtained is the " $\mathrm{D}$ " in total $\mathrm{CO}_{2}$ emissions, and the " $\mathrm{F}$ " in non-renewable primary energy consumption (EPNR). 


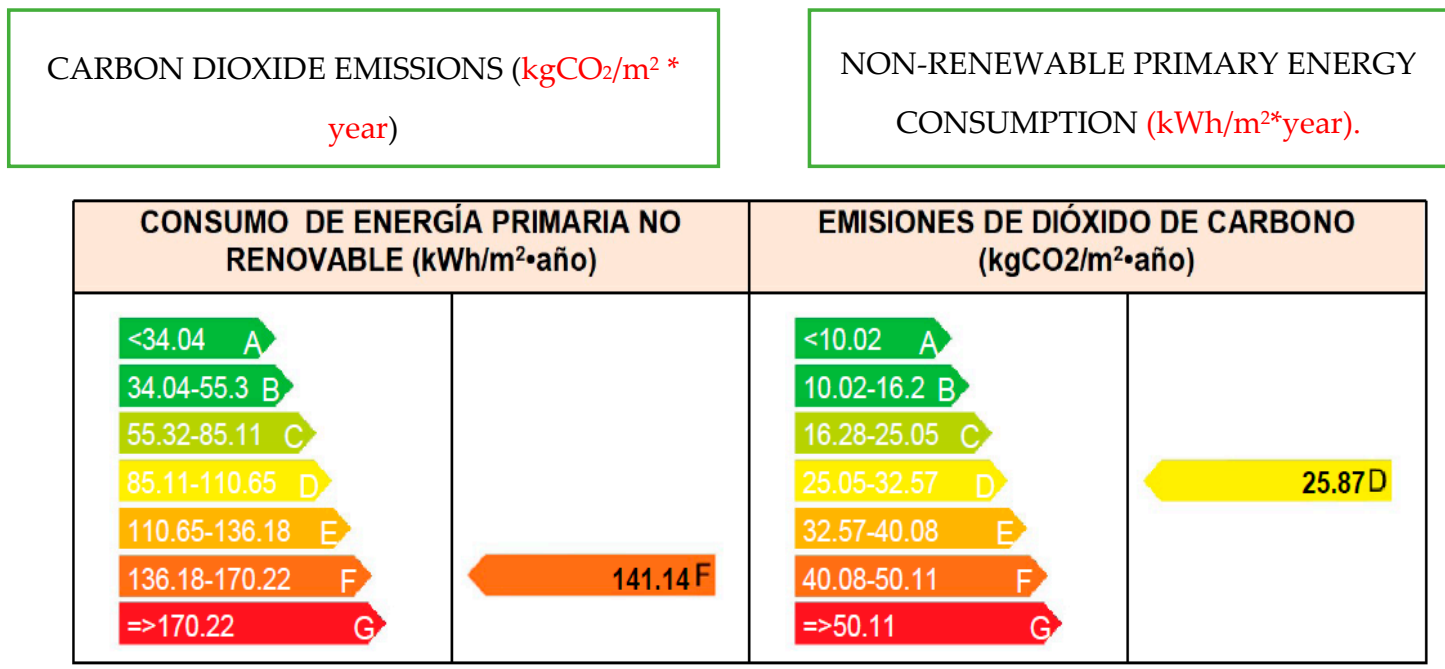

Figure 3. Result obtained in the energy rating of the building with the HULC program.

3.2. Result Obtained with the Improvement Proposals on the Initial Energy Rating of the Building with the General HULC Option

We can see in Table 1 summarizes the results of the proposed improvements on the initial energy rating with the HULC program.

Table 1. Summary table of results obtained with the 8 improvements proposed Source: self-made.

\begin{tabular}{|c|c|c|c|c|}
\hline \multirow[t]{2}{*}{ Proposed Improvements } & \multicolumn{4}{|c|}{ Energy Rating Obtained } \\
\hline & $\begin{array}{c}\text { Consumption } \\
\text { EPNR }\left(\mathrm{KWh} / \mathrm{m}^{2} \cdot \mathrm{añ} o\right)\end{array}$ & Upgrade Scale a & $\begin{array}{c}\text { Emissions } \mathrm{CO}_{2} \\
\left(\mathrm{~kg} \mathrm{CO} / \mathrm{m}^{2} \cdot \mathbf{a n ̃ o}\right)\end{array}$ & Upgrade Scale $^{a}$ \\
\hline M2 & $136.2 \mathrm{~F}$ & 0 letters & $24.5 \mathrm{C}$ & 1 letter \\
\hline M3 & $141.3 \mathrm{~F}$ & 0 letters & $24.8 \mathrm{C}$ & 1 letter \\
\hline M6 & $138.1 \mathrm{~F}$ & 0 letters & $25.3 \mathrm{D}$ & 0 letters \\
\hline M7 & $130.0 \mathrm{C}$ & 3 letters & $22.5 \mathrm{~B}$ & 2 letters \\
\hline M8 & $109.1 \mathrm{C}$ & 3 letters & $19.1 \mathrm{~B}$ & 2 letters \\
\hline
\end{tabular}

a Improvement in the scale with respect to the initial energy rating.

3.3. Comparison of the Result Obtained between the Initial Energy Rating and the M8 Improvement Proposal with the General HULC Option

Considering Improvement 8 as the most interesting in energy and environmental terms. We represent in Table 2 the Comparative analysis of the result obtained between the initial energy rating and the M8 improvement proposal with the general HULC option.

Table 2. Comparison between the initial qualification and the $\mathrm{m} 8$ improvement proposal Source: selfmade.

\begin{tabular}{|c|c|c|c|c|}
\hline \multirow[b]{2}{*}{ Concept } & \multicolumn{4}{|c|}{ Initial and Improved Energy Rating M8 } \\
\hline & $\begin{array}{c}\text { Initial } \\
\text { Qualification }\end{array}$ & $\begin{array}{c}\text { Proposed } \\
\text { Rating M8 }\end{array}$ & $\begin{array}{c}\text { Total } \\
\text { Saving }\end{array}$ & $\%$ Saving \\
\hline Final Energy (kWh/year) & $333,716.4$ & $256,456.1$ & $77,260.3$ & $23 \%$ \\
\hline Final Energy $\left(\mathrm{kWh} /\left(\mathrm{m}^{2} \cdot\right.\right.$ year $\left.)\right)$ & 79.2 & 60.9 & 18.3 & $23 \%$ \\
\hline Energy. Non-renewable primary (kWh/year) & $594,541.8$ & $459,555.8$ & 134,986 & $23 \%$ \\
\hline $\begin{array}{l}\text { Energy. Non-renewable primary } \\
\left(\mathrm{kWh} /\left(\mathrm{m}^{2} \cdot \text { year }\right)\right)\end{array}$ & 141.1 & 109.1 & 32 & $23 \%$ \\
\hline Emisions (kg CO $2 /$ year) & $108,975.3$ & $80,589.5$ & $28,385.8$ & $26 \%$ \\
\hline Emisions (kg CO $2 /\left(\mathrm{m}^{2} \cdot\right.$ year $\left.)\right)$ & 25.9 & 19.1 & 6.8 & $26 \%$ \\
\hline
\end{tabular}




\begin{tabular}{cll}
\hline Qualification. $\mathrm{CO}_{2}$ Emissions & D & B \\
Qualification Energy Primary not Renewable & F & C \\
\hline
\end{tabular}

The results of the proposed improvements on the initial energy qualification with the HULC program are summarized in Table 2.

\subsection{Results Obtained in the Energy Rating of the Building with the Simplified Procedures CE3 and CE3X}

Below we present the results obtained with the simplified calculation procedures CE3 and CE3X

(1). Result of the energy rating of the building with the CE3 program: It has not been possible to obtain a result of the building studied with the proposed geometry, given that the program gives a calculation error, but does not indicate where the fault occurs. It has been tried to introduce the geometry from the file made in HULC (option supported by the program) and directly with the help of the building plans in $\mathrm{dxf}$, and in both cases it is the same, so everything indicates that the CE3 program It collapses with the extensive zoning required for this building, especially when compared to the examples of buildings of Grand Tertiary that the program brings that are much simpler.

(2). Result of the energy rating of the building with the CE3X program: the grade obtained is $\mathrm{E}$ in both total $\mathrm{CO}_{2}$ emissions and in global non-renewable primary energy consumption (EPNR), as can be seen in the following Table 3 and Figure 4.

Table 3. Result of the proposed improvements on the initial energy rating with the CE3X program.

\begin{tabular}{|c|c|c|c|c|}
\hline \multirow[b]{2}{*}{$\begin{array}{c}\text { Proposed } \\
\text { Improvements }\end{array}$} & \multicolumn{4}{|c|}{ Energy Rating Obtained } \\
\hline & $\begin{array}{c}\text { Consumption } \\
\text { EPNR } \\
\text { (KWh/m2·año) }\end{array}$ & $\begin{array}{l}\text { Upgrade } \\
\text { Scale }^{b}\end{array}$ & $\begin{array}{c}\text { Emisions } \mathrm{CO}_{2}(\mathrm{~kg} \\
\left.\mathrm{CO}_{2} / \mathrm{m} 2 \cdot \mathrm{año}\right)\end{array}$ & Upgrade Scale $^{b}$ \\
\hline M1 & $248.8 \mathrm{C}$ & 1 letter & $48.2 \mathrm{D}$ & 1 letter \\
\hline M5 & $276.4 \mathrm{E}$ & 1 letter & $50.3 \mathrm{D}$ & 1 letter \\
\hline M6 & $276.7 \mathrm{E}$ & 0 letters & $55.2 \mathrm{E}$ & 0 letters \\
\hline M8 & $205.5 \mathrm{D}$ & 1 letter & $37.9 \mathrm{C}$ & 2 letters \\
\hline
\end{tabular}

${ }^{\mathrm{b}}$ Improvement in the scale with respect to the initial energy rating.

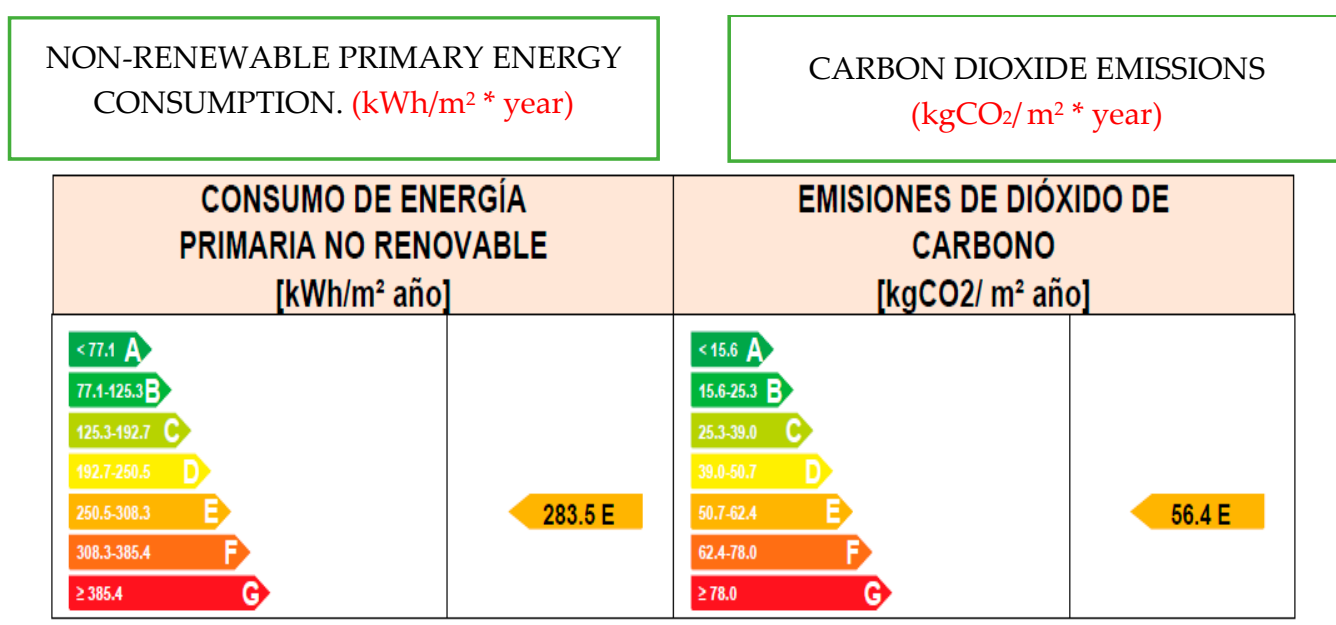

Figure 4. Result obtained in the energy rating of the building with the CE3X program.

\subsection{Comparison of the Result between the Initial Energy Rating Obtained with HULC and CE3X}

Next in Table 4 we comparatively analyze the result between the initial energy rating obtained with HULC and CE3X. 
Table 4. Comparison of the result between the initial energy rating obtained with HULC and CE3X.

\begin{tabular}{|c|c|c|c|c|}
\hline \multirow{2}{*}{ Concept } & \multicolumn{4}{|c|}{ Initial Energy Rating Comparison between HULC and CE3X } \\
\hline & HULC & CEX & Difference Levels ${ }^{c}$ & $\%$ Deviation \\
\hline Heating Demand & $\mathrm{D}$ & $\mathrm{E}$ & $1 \downarrow$ & \\
\hline Heating Demand (kWh/m² year) & 30.9 & 62.8 & & $103 \%$ \\
\hline Refrigeration Demand & $\mathrm{C}$ & $\mathrm{C}$ & 0 & \\
\hline Refrigeration Demand (kWh/m² year) & 11.4 & 34.8 & & $205 \%$ \\
\hline Energy. Non-Renewable Primary & F & E & $1 \uparrow$ & \\
\hline Energy. Non-Renewable Primary $\left(\mathrm{kWh} / \mathrm{m}^{2}\right.$ year) & 141.1 & 283.5 & & $101 \%$ \\
\hline Emisions $\mathrm{CO}_{2}$ & $\mathrm{D}$ & $\mathrm{E}$ & $1 \downarrow$ & \\
\hline Emisione $\left(\mathrm{kg} \mathrm{CO}_{2} / \mathrm{m}^{2}\right.$ year$)$ & 25.9 & 56.4 & & $118 \%$ \\
\hline
\end{tabular}

${ }^{\mathrm{c}}$ Number of levels of difference between the scale obtained in CE3X and that obtained in HULC.

3.6. Comparación del Resultado Entre la Calificación Energética de la Propuesta de Mejora M8 Obtenida con HULC y CE3X

The Table 5 shows the comparative results between the energy rating of the M8 improvement proposal obtained with HULC and CE3X.

Table 5. Comparison of the result between the initial energy rating obtained with HULC and CE3X.

\begin{tabular}{|c|c|c|c|c|}
\hline \multirow{2}{*}{ Concept } & \multicolumn{4}{|c|}{$\begin{array}{l}\text { Comparison of the Proposed Energy Rating of M8 } \\
\text { Improvement between HULC and CE3X }\end{array}$} \\
\hline & HULC & CEX & $\begin{array}{c}\text { Difference } \\
\text { Levels }^{d}\end{array}$ & \% Deviation \\
\hline Heating Demand & $\mathbf{D}$ & $\mathrm{E}$ & $1 \downarrow$ & \\
\hline Heating Demand (kWh/m² year) & 22.2 & 51.3 & & $131 \%$ \\
\hline Refrigeration Demand & C & $\mathrm{C}$ & 0 & \\
\hline Refrigeration Demand $\left(\mathrm{kWh} / \mathrm{m}^{2}\right.$ year) & 12.33 & 30.5 & & $147 \%$ \\
\hline Energy. Non-Renewable Primary & $\mathrm{C}$ & D & $1 \downarrow$ & \\
\hline $\begin{array}{l}\text { Energy. Non-Renewable Primary } \\
\left(\mathrm{kWh} / \mathrm{m}^{2} \text { year }\right)\end{array}$ & 109.1 & 206.5 & & $89 \%$ \\
\hline Emisions $\mathrm{CO}_{2}$ & B & $\mathrm{C}$ & $1 \downarrow$ & \\
\hline Emisione ( $\mathrm{kg} \mathrm{CO} / 2 \mathrm{~m}^{2}$ year) & 19.13 & 37.9 & & $98 \%$ \\
\hline
\end{tabular}

d Number of levels of difference between the scale obtained in CE3X and that obtained in HULC.

\subsection{Result of the Economic Analysis of the Proposed Improvements on the Initial Energy Rating of the} building with the General HULC Option

As indicated in a note in Annex III of the official certificate of energy efficiency of buildings (issued by the energy certification programs), "Energy indicators are calculated based on standard coefficients of operation and operation of the building, so which are only valid for the purpose of your energy rating. For the economic analysis of energy saving and efficiency measures $[13,14]$, the certifying technician must use the actual conditions and historical consumption data of the building". Therefore, in this study the actual consumption data of the building in the building has been taken into account. period between the years 2014-2016. In our case, the difference in consumption between the real final energy (billed) and simulated (general option "HULC") is $-45,387.23 \mathrm{kWh} /$ year, which in percentage would be $13.6 \%$ higher theoretical consumption (simulated) than the real (billing), which we can consider as an acceptable result. Table 6 shows the results of the economic analysis of the proposed improvements on the initial energy rating with the HULC program. 
Table 6. Results of the economic analysis of the proposed improvements on the initial energy rating with the HULC program.

\begin{tabular}{ccccc}
\hline \multirow{2}{*}{$\begin{array}{c}\text { Proposed } \\
\text { Improvements }\end{array}$} & \multicolumn{4}{c}{ Economic Analysis of Improvement Proposals } \\
\cline { 2 - 5 } & $\begin{array}{c}\text { Energy Saving } \\
\text { Simulation (\%) }\end{array}$ & $\begin{array}{c}\text { Investment } \\
\mathbf{( € )}\end{array}$ & $\begin{array}{c}\text { Final Energy Saved } \\
\text { On billing } \\
\text { (kWh/year) }\end{array}$ & $\begin{array}{c}\text { Payback } \\
\text { (years) }\end{array}$ \\
\hline M1 & 5.43 & 79,042 & $15,656.27$ & 50 \\
M5 & 22.06 & 14,728 & $63,605.42$ & 6.5 \\
M6 & 1.94 & 64,421 & 5593.59 & 72 \\
M8h & 15.08 & 30,330 & $43,480.04$ & 4.5 \\
\hline
\end{tabular}

e Percentage of final energy savings according to energy simulation with HULC; ${ }^{\mathrm{f}}$ Final energy saved on real building billing data; $g$ Unit energy prices subject to billing. Maintenance costs are not included.

\section{Conclusions}

With the information provided in this work, it can be observed, how the energy rating of buildings carried out with the HULC tool, allows the energy analysis of the building, showing the current state of the same, and allowing to identify alternatives for improving the energy efficiency of the building, through energy simulations of the proposals to improve the initial energy rating, so from the beginning, those measures that do not entail significant energy savings, and that are not technically feasible or present difficulties in implementation, can be ruled out. As for those alternatives for improvement that involve energy savings or improvement of the energy rating of the building, the results obtained allow an economic study to be carried out to indicate the economic viability of carrying them out. In our case, measures such as increased insulation of the building envelope, biomass boiler or solar thermal installation were discarded from the beginning due to technical difficulties or insignificant energy savings. Regarding the measures finally proposed to improve the energy rating of the Health Center, it should be noted that the return period of the investment shown only refers to the energy savings achieved, which is the object of the study carried out, since if they are taken into account of the maintenance costs of the improvements related to facilities, such return periods would decrease, especially the return period of the replacement of the chillers, since they are obsolete equipment with 19 years old, which is why they include in the proposed improvement, as well as the replacement of windows, which although not being a viable measure from the point of economic life, however, it presents important aspects to take into account, such as the improvement of the energy rating of the building in two levels with the consequent reduction of $\mathrm{CO}_{2}$ emissions, or the improvement of thermal comfort and acoustic comfort of users, as well as the improvement is building technique. Finally we can indicate that after the analysis of the energy rating of the building, and making an investment of $€ 188,521$, corresponding to the energy saving measures of the M8 proposal, the qualification of a 60-year-old Health Center is improved, in two levels in total $\mathrm{CO}_{2}$ emissions, from " $\mathrm{D}$ ", to " $\mathrm{B}$ ", and in three levels in non-renewable primary energy consumption, from " $\mathrm{F}$ " to " $\mathrm{C}$ ", but very close to rating " $\mathrm{B}$ " (see Figure 5), which is that required by the CTE (DB-HE) for new buildings with almost zero energy consumption. Finally, a theoretical saving of $23 \%$ in final energy consumption and $26 \%$ in $\mathrm{CO}_{2}$ emissions is achieved. All this, as a result of having reduced the energy demand for heating of the building, and having improved the energy consumption corresponding to air conditioning and lighting of the Health Center, obtaining as a result a more appropriate qualification to a building belonging to an Administration [15], which must give example, and take measures to avoid exhibiting an F rating, on its energy efficiency label. 


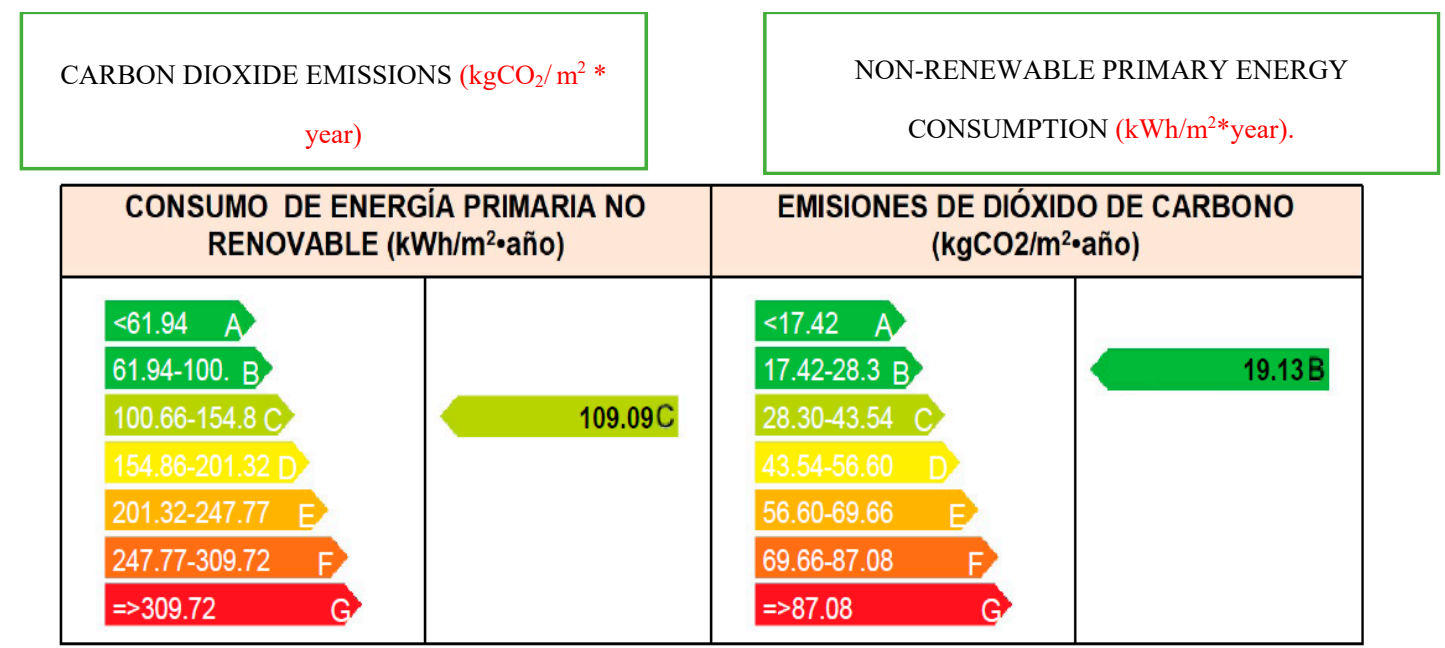

Figure 5. Result obtained in the M8 improvement proposal for the energy rating of the building with the HULC program.

As a summary of this point, it can be said that the analysis of the energy rating of the building allows to identify the most outstanding measures, both from the point of view of energy saving, as well as improving the energy rating scale, as well as discarding other a priori interesting measures, which translates into a tool to help in decision-making, and to be taken into account when rehabilitating and modernizing a building.

Regarding the second part of the purpose of this work, which is the comparison of the results of the energy rating of the building, between the general option HULC, and the simplified procedures CE3 and CE3X, it can be indicated that the rating calculated with the CE3X program, for this building, it does not approximate the qualification obtained with the general option (HULC). On the other hand, with respect to the CE3 tool, for the building geometry established in our case, the program gives errors when carrying out the simulation, so it is not possible to obtain a building qualification.

As can be extracted from the exposed data, of the four main indicators, only one matches the result in CE3X with the HULC rating, both in the initial state, and in the M8 improvement proposal, with the rest of the indicators being above or below, even varying two levels, as is the case with heating demand in the improved M8 situation. As for numerical indicators, in our case, the comparison is not possible due to the large deviation they present, so the data is not valid for energy analysis. It can also be observed, a more conservative nature of the CE3X program versus HULC, which in the opinion of the authors, makes the CE3X program, less interesting from the point of view of energy analysis, a fact that can be verified, when analyzing the results with the proposed improvements to the energy rating in HULC and CE3X, since the results of HULC (" $\mathrm{B}$ " and " $\mathrm{C}$ ") are quite important for a building of this age, while the results of CE3X (" $\mathrm{C}$ " and " $\mathrm{D}$ ") make the improvements proposals are much less attractive and even more thinking that it is a public building that belongs to the Administration, which in turn have an exemplary function over the rest of society.

In summary, in view of the information provided, it can be stated, expressing as carefully as possible, that the simplified procedures for the energy certification of CE3 and CE3x buildings are not suitable for buildings similar to the one studied, that is, buildings of the great tertiary typology (GT), with considerable volume and high number of spaces, affected by various operational conditions. Although it is true, that in order to verify this hypothesis, similar studies should be carried out on a greater number of buildings of this type and in all climatic zones established in the CTE.

Acknowledgments: To the Northern Health Management Area of Jaén belonging to the Andalusian Health Service for access to the data of the building and its facilities, as well as the energy consumption data of the Health Center. 


\section{References}

1. Ballesteros, J.C.; Shaw, A.B. Real Decreto 235/2013 por el que se aprueba el procedimiento básico para la certificación de la eficiencia energética de los edificios. In Consultor de los ayuntamientos y de los juzgados: Revista técnica especializada en administración local y justicia municipal; BOE: Madrid, Spain, 2013.

2. Europeo, P. Directiva 2010/31/UE del Parlamento Europeo y del Consejo, Relativa a la Eficiencia Energética de los Edificios (refundición); DOUE, European Union: Brussels, Belgium, 2010.

3. Documento Básico de Ahorro Energético del Código Técnico de la Edificación (CTE-DB-HE); Ministerio de Fomento: Madrid, Spain, 2017.

4. Pérez Cobos, S. Certificación Energética de Edificios Existentes. In Criterios para la Identificación de la Envolvente Térmica; Marcombo: Barcelona, Spain, 2013.

5. de Iluminación, C.E. Instituto para la Diversificación y Ahorro de Energía (IDAE); Ministerio de Industria y Enegía. Manual de Usuario de la Herramienta Unificada LIDER-CALENER; IDEA: Madrid, Spain, 2017.

6. García Lastra, A. DTIE 7.04: Entrada de Datos al Programa CALENER GT; ATECYR: Madrid, Spain, 2010.

7. García Lastra, A. DTIE 7.03: Entrada de Datos a los Programas LIDER Y CALENER VyP; ATECYR: Madrid, Spain, 2008.

8. de Iluminación, C.E.; Instituto para la Diversificación y Ahorro de Energía (IDAE); Ministerio de Industria y Enegía. Manual de Usuario del Progrma de Calificación Energética de Edificios Existentes CE3; IDAE: Madrid, Spain, 2012.

9. de Iluminación, C.E. Instituto para la Diversificación y Ahorro de Energía (IDAE); Ministerio de Industria y Enegía. Manual de Usuario de Calificación Energética de Edificios Existentes CE3X; IDAE: Madrid, Spain, 2016.

10. Serrano Lanzarote, B. DTIE 18.01 Rehabilitación de la Envolvente Térmica de los Edificios; ATECYR: Madrid, Spain, 2013.

11. Rey Martínez, F.J. Eficiencia Energética de los Edificios. In Certificación Energética; Paraninfo: Madrid, Spain, 2018.

12. Aranda Usón, A. Eficiencia Energética en Instalaciones y Equipamiento de Edificios; Prensas Universitarias de Zaragoza: Zaragoza, Spain, 2010.

13. Acosta Malia, M.J. DTIE 17.01: Análisis Económico de Sistemas Eficientes y Cálculo de Periodo de Retorno de las Inversiones. Estudio de Casos; ATECYR: Madrid, Spain, 2016.

14. Generador de Precios; CYPE Ingenieros: Alicante, Spain, 2019.

15. Instituto para la Diversificación y Ahorro de Energía (IDAE); Turismo y Comercio. Plan de Acción de Ahorro y Eficiencia Energética 2011-2020; Ministerio de Industria: Madrid, Spain, 2011.

(C) 2019 by the authors. Licensee MDPI, Basel, Switzerland. This article is an open access article distributed under the terms and conditions of the Creative Commons Attribution (CC BY) license (http://creativecommons.org/licenses/by/4.0/). 